\title{
COFFEA ARABICA (CV CATUAÍ) PRODUCTION AND BEAN SIZE UNDER DIFFERENT POPULATION ARRANGEMENTS AND SOIL WATER AVAILABILITY ${ }^{1}$
}

\author{
EMILIO SAKAI ${ }^{1}$, EDUARDO A. A. BARBOSA ${ }^{2}$, JANE M. DE C. SILVEIRA ${ }^{3}$, \\ REGINA C. DE M. PIRES ${ }^{4}$
}

\begin{abstract}
The purpose of this research was to evaluate the effect of drip irrigation under different population arrangements on the phytometric features, coffee productivity and bean size classification according to sieve retention. The experiment with Coffea arabica L. cv Catuaí was carried out in Mococa, São Paulo, Brazil. The experimental design was a $6 \times 2$ factorial scheme in randomized blocks, with four replications. The six densities of plantation were E1 $(1.60 \times 0.50 \mathrm{~m})$; E2 $(1.60 \times 0.75 \mathrm{~m})$; E3 (1.60 x $1.00 \mathrm{~m})$; E4 (3.20 x $0.50 \mathrm{~m})$; E5 (3.20 x $0.75 \mathrm{~m})$ and E6 (3.20 x 1.00 $\mathrm{m})$, which were divided according to the availability of water (irrigated - I - or non-irrigated - NI groups). Data were submitted to analysis of variance and averages compared by Tukey test at 1 and $5 \%$ of probability. Descriptive analysis of coffee beans according to sieve classification was performed. Irrigation promoted an increase in plant height, crown diameter and production of processed coffee when compared with the NI group. Interaction between population arrangement and irrigation was observed, with an increase in production and crown diameter as the spacing was decreased. Therefore, irrigation provided significant increase in coffee bean size.
\end{abstract}

KEYWORDS: drip irrigation, coffee productivity, coffee crop phytometry, coffee bean size.

\section{PRODUÇÃO E TAMANHO DE GRÃOS DE CAFÉ (Coffea arabica L.) CV CATUAÍ EM DIFERENTES ARRANJOS POPULACIONAIS E DISPONIBILIDADES DE ÁGUA NO SOLO}

RESUMO: O objetivo deste estudo foi avaliar o efeito da irrigação por gotejamento em diferentes arranjos populacionais nas características fitométricas, na produtividade de café beneficiado e na classificação dos grãos por tamanho, de acordo com a retenção em peneiras. $\mathrm{O}$ experimento foi conduzido em Mococa-SP, com o cafeeiro Coffea arabica L. cv Catuaí. Adotou-se o delineamento experimental em blocos ao acaso, em esquema fatorial $6 \times 2$, com quatro repetições, sendo seis densidades de plantio: E1 (1,60 x 0,50 m); E2 (1,60 x 0,75 m); E3 (1,60 x 1,00 m); E4 (3,20 x 0,50 m); E5 (3,20 x 0,75 m), e E6 (3,20 x 1,00 m), divididas em irrigadas (I) e não irrigadas (NI). As variáveis foram submetidas à análise de variância, e as médias, comparadas entre si pelo teste de Tukey, a 1 e 5\% de probabilidade. Foi realizada análise descritiva dos grãos nas classes de peneiras. A irrigação promoveu aumento na altura das plantas, maior diâmetro de copa e produção de café beneficiado quando comparado ao sistema não irrigado. Houve interação entre arranjo populacional e irrigação, com aumento na produção e no diâmetro da copa, conforme o espaçamento era reduzido. O uso da irrigação propiciou aumentos significativos na granulometria dos grãos de café.

PALAVRAS-CHAVE: irrigação por gotejamento, produção de café, fitometria do cafeeiro, granulometria dos grãos de café.

\footnotetext{
${ }^{1}$ Pesquisador Científico do Instituto Agronômico - IAC, Centro de Pesquisa e Desenvolvimento de Ecofisiologia e Biofísica, Campinas, SP, emilio@iac.sp.gov.br

${ }^{2}$ Doutorando em Engenharia Agrícola, Faculdade de Engenharia Agrícola da Universidade Estadual de Campinas FEAGRI/UNICAMP, Campinas - SP. eduardo.agnellos@gmail.com

${ }^{3}$ Pesquisadora Científica da Agência Paulista de Tecnologia dos Agronegócios - APTA, Polo Nordeste Paulista, Mococa - SP, jane@apta.sp.gov.br

${ }^{4}$ Pesquisadora Científica do Instituto Agronômico - IAC, Centro de Pesquisa e Desenvolvimento de Ecofisiologia e Biofísica, Campinas - SP, rcmpires@iac.sp.gov.br

Recebido pelo Conselho Editorial em: 13-9-2011
}

Aprovado pelo Conselho Editorial em: 16-9-2012 


\section{INTRODUCTION}

Recently, the adoption of irrigation in coffee plantation has gained notoriety in the production system because of the development of equipment and expertise of irrigation in coffee production. Irrigation management has allowed the expansion of coffee production in areas previously considered as marginal or climatically unsuitable for the crop, due to the high water deficit, as well as the maintenance of long-established areas of coffee production, such as the northwestern region of the state of São Paulo, which present a dry season from April to August (ROLIM et al., 2007).

Currently Brazil is the largest coffee producer and exporter, accounting for $25.3 \%$ of world production (FAO, 2008). The productivity per area can be increased with the use of technology such as irrigation that promotes growth in coffee productivity when compared with non-irrigated coffee (CARVALHO et al., 2006 and SILVA et al., 2008).

CARVALHO et al. (2006), when comparing irrigated and non-irrigated Rubi MG-1192 coffee crop, found an increase in crown diameter and in plant height in the irrigated treatment. The greater development of aerial part, plant height and crown diameter means increased production of nodes available for the formation of flowers, and consequently resulting in increased fruit production.

According to SILVA et al. (2008), in a study with irrigated coffee, during the initial four crop carried out in Uberlândia, drip irrigation promoted increased in productivity when compared with the non-irrigated plantation. However, for the successful adoption of the irrigation system, improved yielding techniques are required in order to counterbalance the investment in irrigation systems.

The adoption of new technologies in agriculture requires studies of population arrangement, which allows maximizing the production system. PEREIRA et al. (2007) found that the appropriate management of spacing in coffee crop ensured good yield. Taking into account the incorporation of new technologies in coffee production, mastery of knowledge of the main factors related to the production is mandatory. Therefore, the present work aimed at evaluating the use of drip irrigation on the phytometric features, productivity of processed coffee and bean size and type of the second Coffea arabica L. cv Catuaí harvest, under different population arrangements.

\section{MATERIAL AND METHODS}

The experiment was carried out in the Agribusiness Technological Development Cluster of Northeast of the state of São Paulo, located at latitude $21^{\circ} 28^{\prime} \mathrm{S}$, longitude $47^{\circ} 00^{\prime} \mathrm{W}$ and altitude $663 \mathrm{~m}$. Seedlings of Coffea arabica L. cultivar Yellow Catuaí were transplanted between March 6th and 7th, 2006, and the 2008/2009 crop cycle was assessed.

The experimental design was a $6 \times 2$ factorial scheme in randomized blocks, with four replications. The six densities of plantation were E1 $(1.60 \times 0.50 \mathrm{~m})$; E2 $(1.60 \times 0.75 \mathrm{~m})$; E3 $(1.60 \mathrm{x}$ $1.00 \mathrm{~m})$; E4 $(3.20 \times 0.50 \mathrm{~m})$; E5 $(3.20 \times 0.75 \mathrm{~m})$ and E6 $(3.20 \times 1.00 \mathrm{~m})$, corresponding to 12,500; 8,$333 ; 6,250 ; 6,250 ; 4,127$ and 3,125 plants $\mathrm{ha}^{-1}$, respectively, which were divided according to the availability of water (irrigated - I - or non-irrigated - NI - groups).

Before beginning the experiment, soil samples from the experimental area were collected at 0 $0.20 ; 0.20-0.40$ and $0.40-0.60 \mathrm{~m}$ depth. Hydric characterization was performed through soil water retention curve with undisturbed samples. For the extraction of water, Richards extractor device was used, which allowed obtaining the values of volumetric water content in soil $(\theta)$ as a function of soil water potential $\left(\psi_{\mathrm{s}}\right)$. Using these values, equations were adjusted for each depth and presented in Table 1. 
TABLE 1. Equation of the relation between volumetric water content $\left(\theta\right.$, in $\left.\mathrm{cm}^{3} \mathrm{~cm}^{-3}\right)$ and the matrix potential of water in the soil ( $\psi \mathrm{s}$, in $\mathrm{MPa})$, in the following depths: $0-0.20 ; 0.20$ 0.40 and 0.40-0.60 m, in Guaíra - SP, Brazil. Each adjustment was performed with 10 pairs of values $(\mathrm{n})$.

\begin{tabular}{ccc}
\hline $\begin{array}{c}\text { Depth } \\
(\mathrm{m})\end{array}$ & $\begin{array}{r}\text { Volumetric Water Content in Soil } \\
\left(\theta=\mathrm{m}^{3} \mathrm{~m}^{-3}, \psi_{\mathrm{s}}=10^{2} \mathrm{KPa}\right)\end{array}$ & $\begin{array}{c}\text { Regression Coefficient } \\
\left(\mathrm{R}^{2}\right)\end{array}$ \\
\hline $0-0.20$ & $\theta=0.3349\left(\psi_{\mathrm{s}}\right)^{-0.0506}$ & 0.90 \\
$0.20-0.40$ & $\theta=0.3831\left(\psi_{\mathrm{s}}\right)^{-0.0388}$ & 0.89 \\
$0.40-0.60$ & $\theta=0.3986\left(\psi_{\mathrm{s}}\right)^{-0.0319}$ & 0.89 \\
\hline
\end{tabular}

Soil samples at $0-0.20 ; 0.20-0.40$ and $0.40-0.60 \mathrm{~m}$ depth, were referred to physical and chemical characterization, and the values are presented in Table 2. The experimental area was classified as medium textured eutrophic red argisoil (EMBRAPA, 2006).

TABLE 2. Particle-size and chemical analyses of soil in the experimental area in Mococa - SP, Brazil.

\begin{tabular}{|c|c|c|c|c|}
\hline Depth & & $0-0.2 \mathrm{~m}$ & $0.2-0.4 \mathrm{~m}$ & $0.4-0.6 \mathrm{~m}$ \\
\hline Coarse sand & $\mathrm{g} \mathrm{kg}^{-1}$ & 19 & 27 & 17 \\
\hline Fine sand & $\mathrm{g} \mathrm{kg}^{-1}$ & 7 & 10 & 9 \\
\hline Silt & $\mathrm{g} \mathrm{kg}^{-1}$ & 57 & 55 & 70 \\
\hline Clay & $\mathrm{g} \mathrm{kg}^{-1}$ & 17 & 8 & 4 \\
\hline Density & $\mathrm{g} \mathrm{cm}^{-3}$ & 1.04 & 1.02 & 1.00 \\
\hline Porosity & $\%$ & 53.2 & 55.4 & 54.4 \\
\hline $\mathrm{pH}$ in $\mathrm{CaCl}_{2}$ & - & 5.8 & 5.6 & 5.6 \\
\hline $\mathrm{pH}$ in $\mathrm{H}_{2} \mathrm{O}$ & - & 6.7 & 6.4 & 6.4 \\
\hline $\mathrm{H}$ & $\mathrm{mmol}_{\mathrm{c}} \mathrm{dm}^{-3}$ & 37 & 41 & 33 \\
\hline $\mathrm{Al}$ & $\mathrm{mmol}_{\mathrm{c}} \mathrm{dm}^{-3}$ & 1.0 & 1.0 & 1.0 \\
\hline OM & $\%$ & 2.0 & 1.1 & 0.6 \\
\hline $\mathrm{P}$ & $\mathrm{mg} \mathrm{dm}^{-3}$ & 24.4 & 11.1 & 5.6 \\
\hline $\mathrm{K}$ & $\mathrm{mmol}_{\mathrm{c}} \mathrm{dm}^{-3}$ & 7.5 & 4.4 & 2.8 \\
\hline $\mathrm{Ca}$ & $\mathrm{mmol}_{\mathrm{c}} \mathrm{dm}^{-3}$ & 32 & 26 & 19 \\
\hline $\mathrm{Mg}$ & $\mathrm{mmol}_{\mathrm{c}} \mathrm{dm}^{-3}$ & 10 & 9 & 10 \\
\hline CEC & $\mathrm{mmol}_{\mathrm{c}} \mathrm{dm}^{-3}$ & 87.5 & 81.4 & 65.8 \\
\hline BS & $\%$ & 56.6 & 67.0 & 60.7 \\
\hline
\end{tabular}

OM - organic matter; CEC - cation exchange capacity; BS - base saturation

Fertilization was performed according to the Bulletin 200 of the Campinas Agronomic Institute (FAZUOLLI et al., 1998) based on the result of the soil chemical analysis. Fertigation was performed once a week, except during water restriction period (July-August). The soluble fertilizer was 19-06-20 Maxsol, with annual dose of $450 \mathrm{~kg} \mathrm{ha}^{-1}$. In the non-irrigated treatments, three applications of 20-05-20 fertilizer was manually performed (450 $\left.\mathrm{kg} \mathrm{ha}^{-1}\right)$ along with the rainy months (October, November and January).

During the experiment, meteorological data were daily collected from the Automatic Weather Station located approximately $500 \mathrm{~m}$ from the experimental area. The values of average air temperature and precipitation during the 2008/2009 crop cycle are illustrated in Figure 1 . The climate according to Köppen is Cwa, featuring dry winters and warm and wet summers (ROLIM et al., 2007). 


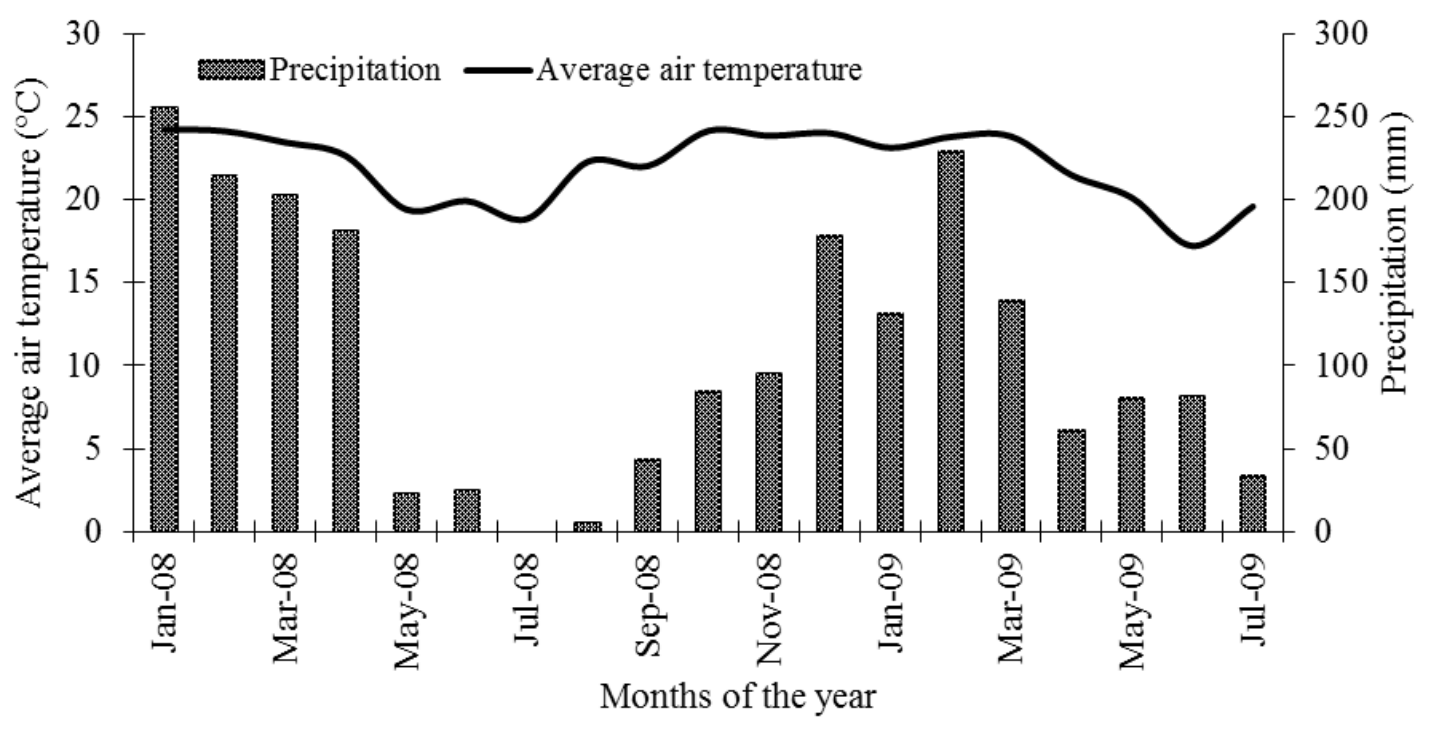

FIGURE 1. Average air temperature and precipitation occurred in the experimental area during the 2008/2009 crop cycle in Mococa - SP, Brazil.

The irrigation system was surface drip irrigation, with emitter flow rate of $2.3 \mathrm{~L} \mathrm{~h}^{-1}$ and emitter spacing of $0.50 \mathrm{~m}$. The amount of water applied depended on the irrigation interval, the climatic demand (reference evapotranspiration), undertaken by the Penman-Monteith method, of estimated crop evapotranspiration, according to ALLEN et al. (1998), and the vegetation cover of $40 \%$, based on the spacing between the rows (1.6 and $3.2 \mathrm{~m})$.. Irrigation was daily applied conform to the climatic demand. Irrigation was suspended for 60 days during July and August for the imposition of water deficit, in order to promote uniformity of flowering, as established by SILVA et al. (2009).

Phytometric analyses were performed on February 27, 2009, i.e. around 36 months after planting. The phytometric parameters analyzed were: plant height $(\mathrm{m})$, crown diameter $(\mathrm{m})$ and stem diameter $(\mathrm{cm})$. The plants were randomly chosen in the useful area of the parcel. Measures of height and crown diameter were performed with the aid of a measuring tape. Crown diameters were made in the horizontal direction to the plantation row. The stem diameters were measured with the aid of a caliper, $0.1 \mathrm{~m}$ from the soil surface.

The harvest of irrigated coffee was performed on April 3, 2009, and that of non-irrigated one on June 16, 2009. The early harvest in the irrigated group was due to the early fruit maturation. The crop was harvested in a sieve thus preventing fruit falling on the ground.

The number of plants harvested from each parcel was as follows: 9 plants in the $0.50 \mathrm{~m}$ spacing; 6 plants in the $0.75 \mathrm{~m}$ spacing; and 5 plants in the $1.00 \mathrm{~m}$ spacing. Additionally, 3 rows were harvested in the $1.60 \mathrm{~m}$ spacing between rows, and one central row in the $3.20 \mathrm{~m}$ spacing. Coffee production in each parcel was divided by the number of plants harvested per parcel, thus the average production of a plant was gotten. Afterwards, the average production of each plant per parcel was multiplied by the number of plants per hectare, which allowed obtaining the productivity, in $\mathrm{kg} \mathrm{ha}^{-1}$, in each population arrangement.

The processing of freshly harvested coffee was done using the conventional terrace drying method. The production of coffee cherries from each plant was stored separately in nylon bags and let it dry in the sun, constantly revolving throughout the day. After 45 days of drying, the husk and parchment were removed. The output was calculated as the ratio between the weight of processed coffee and the dry coffee cherry.

Values of the average sieve were determined in samples of 100 grams of processed coffee per treatment. After removal of the endocarp, the flat beans were separated through a set of sieves, with 
round opening between 23 and 12, and the peaberry beans were retained on sieve 11. The types of beans (flat and peaberry) retained on the sieves were weighed on precision balance for further statistic analysis.

Data regarding phytometric parameters, production of processed coffee, yield of processed beans, average sieve, and type of beans were subjected to analysis of variance followed by Tukey test at 1 and $5 \%$ of probability. Descriptive statistical analysis was performed on the curves of bean distribution in the different grades of sieves.

\section{RESULTS AND DISCUSSION}

\section{Plant height}

The height of Catuaí coffee tree, 36 months after planting, was significantly affected by the different arrangements $(p<0.05)$ and the use of irrigation $(p<0.01)$, but it could not be seen significant interaction between arrangement and irrigation (Table 3). Coffee trees cultivated under E1 arrangement were significantly taller $(1.52 \mathrm{~m})$ than those under E3, E5 and E6 arrangements. Coffee trees in the E2 arrangement were statistically different from those in E5 and E6.

Overall, the plants under the greater planting density were the tallest ones. CARVALHO et al. (2006), evaluating the effect of irrigation on the Rubi variety in different spacing, found that irrigation significantly affect plant height after reaching $0.9 \mathrm{~m}$ and reported that regardless of irrigation regimen, the denser the planting the taller the plants.

NACIF (1997), evaluating the height of Catuaí coffee under different planting densities, observed a linear increase in height after 31 months of planting as the crowding was reduced, which was attributed to the shading. MARTINEZ et al. (2007) also found an increase in plant height 33 months after planting as planting space was decreased, confirming our results.

The average height of irrigated plants was $25 \mathrm{~cm}(16.5 \%)$ superior to the average height of non-irrigated ones. MOREIRA et al. (2004), evaluating different population arrangements of 36month old coffee tree cultivated with and without irrigation found that irrigated plants were significantly taller than the non-irrigated ones. These authors did not find interaction between population arrangement and irrigation on coffee tree height, corroborating the results of the present study.

PAIVA (2006) reported that the growth of coffee trees is directly related to soil water availability, and that the water supply through irrigation during the driest season allows the higher grow of the plants when compared to the non-irrigated ones.

\section{Crown diameter}

The different population arrangements did not provide significant effects on crown diameter by 36 months after planting (Table 3), which indicates that there are no alterations in crown development due to the effect of different population arrangements. These results are in accordance with those obtained by CARVALHO et al. (2006), who studied two planting densities, 2,500 and 10,000 plants $\mathrm{ha}^{-1}$, and did not verified alteration in crown diameter of the Rubi variety by 34 months after planting.

Irrigation provided greater development of the plants, with crown diameters statistically different when compared with those from the non-irrigated group $(\mathrm{p}<0.01)$, as illustrated in Table 3 and corroborating the results obtained by CARVALHO et al. (2006).

Crown diameter of the irrigated plants was on average $24 \mathrm{~cm}(17 \%)$ superior to that of nonirrigated plants, showing an increased growth of plagiotropic branches. MOREIRA et al. (2004) verified that the irrigated plants presented statistically significant longer platiogropic branches 36 months after planting and less free space between plants 41 months after planting, thus evidencing a greater development of the aerial part in the plants under irrigation. 
There was a significant irrigation $\mathrm{x}$ spacing interaction $(\mathrm{p}<0.05)$ for crown diameter, indicating a synergistic effect of both sources of variation. The result of this interaction reveals the occurrence of a combined effect of irrigation on E1, E4, E5 and E6 arrangements, as illustrated in Table 4. The greater crown diameter was obtained in irrigation group under E1 arrangement, although not statistically different from irrigated treatments under E2, E4, E5 and E6 arrangements.

\section{Stem diameter}

Stem diameter of Catuaí coffee tree, 36 months after planting, differed significantly due to spacing $(p<0.05)$ and irrigation $(p<0.01)$, but no significant effect of population arrangement $x$ irrigation interaction was seen, as demonstrated in Table 3.

Plants cultivated in E3 arrangement presented larger stem diameter than those in the other treatments, and it was statistically different from the stem diameter of plants cultivated in the lowest plant population (E1). Stem diameter was larger in the irrigated groups, as illustrated in Table 3. This result is in agreement with that obtained by MOREIRA et al. (2004), who verified the superiority of stem diameter in the irrigated treatment in relation to the non-irrigated one, although no population arrangement $\mathrm{x}$ irrigation interaction was seen in this variable.

MARTINEZ et al. (2007), examining the vegetative growth and its correlation with the productivity of different varieties of coffee trees cultivated at different spacing, found that the variables plant height, crown diameter and stem diameter presented good correlation with productivity and are very important parameters in the definition of coffee yield.

Plants that undergo a period of water stress have their stomata aperture reduced, thus decreasing their growth rate due to reduction in photosynthetic rate. Therefore, during the drought, plants reduce the assimilation of $\mathrm{CO}_{2}$ and consequently their growth and photosynthesis in order to prevent water losses by transpiration (TAIZ \& ZEIGER, 2008).

TABLE 3. Analysis of variance for plant height, crown diameter, stem diameter, yield of processed coffee and productivity of processed coffee, cv. Catuaí, cultivated in different population arrangements (PA), with or without irrigation, in 2008/2009 harvest, in Mococa - SP, Brazil.

\begin{tabular}{|c|c|c|c|c|c|c|}
\hline & & Plant height & $\begin{array}{c}\text { Crown } \\
\text { diameter }\end{array}$ & $\begin{array}{c}\text { Stem } \\
\text { diameter }\end{array}$ & $\begin{array}{c}\text { Yield of } \\
\text { processed coffee }\end{array}$ & $\begin{array}{c}\text { Productivity of } \\
\text { processed coffee }\end{array}$ \\
\hline & & \multicolumn{2}{|c|}{$\mathrm{m}$} & $\mathrm{cm}$ & $\%$ & $\mathrm{~kg} \mathrm{ha}^{-1}$ \\
\hline \multirow{6}{*}{$\begin{array}{c}\text { Population } \\
\text { arrangement (PA) } \\
(\mathrm{m})\end{array}$} & E1 - $1.60 \times 0.50$ & $1.52 \mathrm{a}$ & $1.35 \mathrm{a}$ & $0.29 \mathrm{~b}$ & $52.7 \mathrm{a}$ & $2,979 \mathrm{a}$ \\
\hline & $\mathrm{E} 2-1.60 \times 0.75$ & $1.44 \mathrm{ab}$ & $1.27 \mathrm{a}$ & $0.31 \mathrm{ab}$ & $52.9 \mathrm{a}$ & $3,173 \mathrm{a}$ \\
\hline & E3 $-1.60 \times 1.00$ & $1.35 \mathrm{bc}$ & $1.36 \mathrm{a}$ & $0.36 \mathrm{a}$ & $53.3 \mathrm{a}$ & $2,894 \mathrm{a}$ \\
\hline & $\mathrm{E} 4-3.20 \times 0.50$ & $1.40 \mathrm{abc}$ & $1.29 \mathrm{a}$ & $0.32 \mathrm{ab}$ & $52.7 \mathrm{a}$ & $1,627 \mathrm{~b}$ \\
\hline & E5 - $3.20 \times 0.75$ & $1.28 \mathrm{c}$ & $1.23 \mathrm{a}$ & $0.33 \mathrm{ab}$ & $53.5 \mathrm{a}$ & $1,835 \mathrm{~b}$ \\
\hline & $\mathrm{E} 6-3.20 \times 1.00$ & $1.27 \mathrm{c}$ & $1.24 \mathrm{a}$ & $0.33 \mathrm{ab}$ & $52.9 \mathrm{a}$ & $1,373 \mathrm{~b}$ \\
\hline $\mathrm{F}$ test for PA & & $8.01 *$ & $1.97 \mathrm{~ns}$ & $2.94 *$ & $0.19 \mathrm{~ns}$ & $25 * *$ \\
\hline SAD & & 0.14 & - & 0.056 & - & 672 \\
\hline \multirow{2}{*}{ Irrigation (I) } & With & $1.50 \mathrm{a}$ & $1.41 \mathrm{a}$ & $0.34 \mathrm{a}$ & $53.4 \mathrm{a}$ & $3,775 \mathrm{a}$ \\
\hline & Without & $1.25 \mathrm{~b}$ & $1.17 \mathrm{~b}$ & $0.30 \mathrm{~b}$ & $52.6 \mathrm{a}$ & $853 \mathrm{~b}$ \\
\hline F test for I & & $87.5 * *$ & $57.6 * *$ & $14.3 * *$ & $1.41 \mathrm{~ns}$ & $517 * *$ \\
\hline SAD & & 0.055 & 0.065 & 0.021 & - & 261 \\
\hline$F$ test for I x PA & & $2.36 \mathrm{~ns}$ & $3.14 *$ & $1.77 \mathrm{~ns}$ & $0.49 \mathrm{~ns}$ & $10 * *$ \\
\hline SAD & & - & 0.23 & - & - & 951 \\
\hline C.V. \% & & 6.8 & 8.6 & 11.4 & 4.19 & 19.23 \\
\hline General mean & & 1.38 & 1.29 & 0.32 & 53.0 & 2,314 \\
\hline
\end{tabular}


TABLE 4. Average crown diameter and productivity of processed coffee according to the adoption of irrigation in different population arrangement as well as of every population arrangement according to the adoption of irrigation in the 2008/2009 harvest, in Mococa - SP, Brazil.

\begin{tabular}{|c|c|c|c|c|c|c|}
\hline \multirow{3}{*}{$\begin{array}{l}\text { Population Arrangement } \\
\text { (m) }\end{array}$} & \multicolumn{3}{|c|}{$\begin{array}{l}\text { Crown Diameter } \\
(\mathrm{m})\end{array}$} & \multicolumn{3}{|c|}{$\begin{array}{l}\text { Productivity of Processed Coffee } \\
\qquad\left(\mathrm{kg} \mathrm{ha}^{-1}\right)\end{array}$} \\
\hline & \multicolumn{6}{|c|}{ Irrigation } \\
\hline & With & Without & & With & Without & \\
\hline F test & $2.61 *$ & $2.51 *$ & F test & $33.4 * *$ & $1,8^{\mathrm{ns}}$ & $F$ test \\
\hline E1 - $1.60 \times 0.50$ & $1.55 \mathrm{aA}$ & $1.15 \mathrm{abB}$ & $27 * *$ & 4,995 a $\mathrm{A}$ & 963 a B & $164 * *$ \\
\hline E2 $-1.60 \times 0.75$ & $1.30 \mathrm{bA}$ & $1.23 \mathrm{abA}$ & $0.93^{\mathrm{ns}}$ & 5,109 а $A$ & 1,238 a B & $151 * *$ \\
\hline E3 $-1.60 \times 1.00$ & $1.42 \mathrm{abA}$ & $1.30 \mathrm{aA}$ & $2.21^{\mathrm{ns}}$ & 4,675 a $A$ & 1,113 a B & $128 * *$ \\
\hline $\mathrm{E} 4-3.20 \times 0.50$ & $1.46 \mathrm{abA}$ & $1.13 \mathrm{abB}$ & $17 * *$ & $2,577 \mathrm{~b} \mathrm{~A}$ & 678 a B & $36 * *$ \\
\hline E5 - $3.20 \times 0.75$ & $1.41 \mathrm{abA}$ & $1.05 \mathrm{bB}$ & $22 * *$ & $2,965 \mathrm{~b} \mathrm{~A}$ & 706 a B & $52 * *$ \\
\hline E6 - $3.20 \times 1.00$ & $1.33 \mathrm{abA}$ & $1.16 \mathrm{abB}$ & $4.91 *$ & $2,326 \mathrm{~b} \mathrm{~A}$ & 421 a B & $37 * *$ \\
\hline
\end{tabular}

* Significant at $5 \%$ of probability; ** Significant at $1 \%$ of probability; ns - non significant. Lower cases represent average values in the column and upper cases represent average values in the row.

\section{Productivity and yield of processed coffee}

The yield of processed coffee was significantly affected by different population arrangements $(\mathrm{p}<0.05)$ and use of irrigation $(\mathrm{p}<0.01)$. In addition, there was a significant population arrangement $\mathrm{x}$ irrigation interaction $(\mathrm{p}>0.01)$ for the variable crown diameter and yield of processed coffee, as shown in Table 3.

The treatments with $1.60 \mathrm{~m}$ spacing between planting rows presented significant differences when compared with the treatments with spacing of $3.20 \mathrm{~m}$. Coffee trees cultivated in $1.60 \mathrm{~m}$ spacing had a $46.5 \%$ higher average productivity than those cultivated in $3.20 \mathrm{~m}$ spacing. The highest productivity was obtained in the coffee trees cultivated in the E2 arrangement $\left(3,173 \mathrm{~kg} \mathrm{ha}^{-1}\right)$, although not statistically different from plants in E1 and E3. The productivity of the coffee tree cultivated in E2 arrangement was around 57\% higher than that of coffee tree in E6.

It is worth mentioning that despite the similar planting density in E3 and E4 arrangements $\left(6,250\right.$ plants $\left.\mathrm{ha}^{-1}\right), \mathrm{E} 3$ treatment showed a higher productivity of processed coffee (approximately $44 \%$ ) when compared with $\mathrm{E} 4$, which indicates that the spacing between rows has greater influence on productivity in the third year of cultivation of Catuaí coffee tree than the spacing among plants. MOREIRA et al. (2004) found significant effects of the spacing between planting rows on Mundo Novo coffee tree productivity. Treatments with smaller spacing between the planting rows showed the highest productivity of processed coffee.

In the irrigated group, there was a significant increase in productivity of processed coffee, with an average productivity of $3,775 \mathrm{~kg} \mathrm{ha}^{-1}$ (Table 3). In this group, productivity of processed coffee was $77 \%$ higher than that in the non-irrigated group, i.e. there was an increment of 49 bags ha $^{-1}$ in the irrigated plants. Increases in coffee yield due to irrigation have been reported by COSTA et al. (2010) and SILVA et al. (2008) who found $51 \%$ and $62 \%$ of increment in the productivity, respectively, the latter when analyzing the average yield of four years. FLUMIGNAN et al. (2011) in a study in Paraná also found a higher productivity of irrigated coffee in relation to non-irrigated.

COSTA et al. (2010) found irrigated and fertigated provided significant increases to the number of primary branches and yield of coffee Obatã. These authors reported that this was due to synergistic effect of irrigation associated with fertigation, providing better use of nutrients presents in fertilizer. 
FREITAS et al. (2007) found that the length of primary branches and height of the coffee has a good relationship with the productivity of coffee. Irrigated plants had the highest phytometric values, possibly influencing the increase in productivity. To MARTINEZ et al. (2007) improvements in farming brought about by the use of irrigation, such as increased plant height, crown diameter and stem diameter, enhance the production capacity.

QUAGGIO \& RAIJ (2009) reported that production of fertirrigated coffee trees in the second year is 40 bags ha $^{-1}$ superior to the production of non-irrigated coffee trees, counterbalancing the investments due to the adoption of irrigation in coffee production.

The result of interaction for the productivity of processed coffee reveals the effect of spacing only in the irrigated group (Table 4). The irrigated coffee trees, cultivated at spacing of $1.6 \mathrm{~m}$ between planting rows, had higher productivity $(47 \%)$ of processed coffee when compared with those cultivated at spacing of $3.2 \mathrm{~m}$ between rows $(\mathrm{p}<0.01)$. Therefore, during the first three years of cultivation, the adoption of irrigation is advantageous in the denser crops, ensuring higher production of processed coffee in the first crop cycles.

Within each spacing, irrigation provided significant effects in every population arrangements $(p<0.01)$. A $74-82 \%$ increase in productivity was observed with the irrigated plants when compared with the non-irrigated coffee trees. These findings highlight the benefit of irrigation in coffee plantation, improving productivity irrespective of the adopted spacing. The yield of processed coffee, i.e., the resulting amount of coffee after the beneficiation process, was not altered by population arrangement and water availability (Table 3). The average yield of processed coffee after beneficiation process was $53 \%$.

SANTOS (2005), analyzing two harvest of 5 and 6-year old Mundo Novo coffee trees, submitted to irrigation treatment at different spacing, found that the spacing affected significantly the yield in the harvest of 5-year old coffee trees, with a trend of yield reduction as the spacing between plants decreases, and with an increasing in the denser spacing $(1.75 \times 0.75 \mathrm{~m})$. In the harvest of 6-year old coffee trees, no spacing effect on yield was detected. The average yield value (54\%) was close to that obtained in the present study.

\section{Bean size and type}

The values of average sieve, which were between 17.6 and 18.4 for E6 and E1 arrangements, respectively, were not significantly different $(\mathrm{p}<0.05)$ in the population arrangements (Table 5). The coffee crops in the larger population arrangements have increased availability of radiation due to lower shading, and consequently greater ability to perform photosynthesis and to provide photosynthate for bean filling. On the other hand, the trees grown in smaller spacing presented higher bean yields per plant (REZENDE et al., 2006), increasing the competition for assimilates by the plant drains and resulting in an average sieve similar to that of plants that were grown in the larger population arrangements.

Irrigation provided significant change in bean size $(\mathrm{p}<0.01)$. The average sieve for the irrigated group was 18.8 while that for the non-irrigated one was 17.4 (Table 5). REZENDE et al. (2006) reported an increase of coffee bean size with the use of irrigation. CUSTODIO et al. (2007), analyzing five harvests of irrigated coffee trees, cv. Rubi, detected effect of irrigation on bean size only in the third harvest.

A good water supply provides better conditions for plant development, which reflects in greater bean filling and larger bean formation, since water acts directly on cell expansion and also on the transportation of photosynthates from leaves to fruit (TAIZ \& ZEIGER, 2008). CAMARGO \& CAMARGO (2001) reports that, under the conditions of Mid-South region of Brazil, water deficit in the pellet-like berries (October-December) delays fruit growth, results in lower sieve and decreases the productivity, which are non-desirable for commercialization. 
Flat bean was significantly influenced by population arrangement $(\mathrm{p}<0.05)$. Coffee tree cultivated at $3.20 \times 0.75 \mathrm{~m}$ spacing provided greater percentage of flat beans, which differs from the coffee trees cultivated at $1.60 \times 0.75 \mathrm{~m}$ spacing (Table 5). Overall, plants grown at spacing of $1.60 \mathrm{~m}$ between planting rows presented lower values of flat beans than those cultivated at $3.20 \mathrm{~m}$ of spacing. There was effect neither of irrigation nor of the irrigation $\mathrm{x}$ population arrangement interaction on the formation of flat beans.

TABLE 5. Analysis of variance for average sieve and type of Catuaí coffee bean (flat or peaberry), cultivated in different population arrangements (PA), with or without irrigation, in 2008/2009 harvest, in Mococa - SP, Brazil.

\begin{tabular}{|c|c|c|c|c|}
\hline & & \multirow{2}{*}{ Average Sieve } & \multicolumn{2}{|c|}{ Type of Bean } \\
\hline & & & Flat & Peaberry \\
\hline \multirow{6}{*}{$\begin{array}{l}\text { Population arrangements } \\
\qquad(\mathrm{m})\end{array}$} & E1 - $1.60 \times 0.50$ & $18.4 \mathrm{a}$ & $66.6 \mathrm{ab}$ & $16.5 \mathrm{a}$ \\
\hline & $\mathrm{E} 2-1.60 \times 0.75$ & $18.2 \mathrm{a}$ & $63.4 \mathrm{~b}$ & $18.9 \mathrm{a}$ \\
\hline & $\mathrm{E} 3-1.60 \times 1.00$ & $18.1 \mathrm{a}$ & $63.8 \mathrm{ab}$ & $17.7 \mathrm{a}$ \\
\hline & $\mathrm{E} 4-3.20 \times 0.50$ & $18.1 \mathrm{a}$ & $68.7 \mathrm{ab}$ & $16.9 \mathrm{a}$ \\
\hline & E5 $-3.20 \times 0.75$ & $18.2 \mathrm{a}$ & $69.8 \mathrm{a}$ & $15.6 \mathrm{a}$ \\
\hline & $\mathrm{E} 6-3.20 \times 1.00$ & $17.6 \mathrm{a}$ & $67.4 \mathrm{ab}$ & $16.9 \mathrm{a}$ \\
\hline$F$ test for PA & & $2.47^{+}$ & $2.98^{*}$ & 0.78 \\
\hline SAD & & & 6.3 & \\
\hline \multirow[t]{2}{*}{ Irrigation (I) } & With & $18.8 \mathrm{a}$ & 67.6 & $12.3 \mathrm{~b}$ \\
\hline & Without & $17.4 \mathrm{~b}$ & 65.7 & $21.8 \mathrm{a}$ \\
\hline F test for I & & $99.70 * *$ & $2.57^{+}$ & $83.51 * *$ \\
\hline SAD & & 0.28 & - & 2.11 \\
\hline$F$ test for I $x$ PA & & 0.65 & 0.62 & 1.21 \\
\hline SAD & & - & - & - \\
\hline C.V. \% & & 2.72 & 6.28 & 21.1 \\
\hline General mean & & 18.1 & 66.6 & 17 \\
\hline
\end{tabular}

** Significant at $1 \%$ of probability by Tukey test. * Significant at 5\% of probability by Tukey test. ${ }^{+}$Significant at $10 \%$ of probability by Tukey test. SAD - significant average deviation; C.V. - coefficient of variation.

Peaberry bean was not influenced by the population arrangement, as seen in Table 5. The percentage of peaberry beans in the population arrangements is above the acceptable values for exports (12\%), and may be related to the adverse environmental effects, such as the high temperature during flowering. PEZZOPANE et al. (2007) verified that an average air temperature close to $24^{\circ} \mathrm{C}$ provided high productivity of peaberry beans, which affected the quality of beans. In the experiment, flowering occurred at $25^{\circ} \mathrm{C}$ during September/October, as illustrated in Figure 1.

In the irrigated group, the production of peaberry beans was very close to the accepted values for exports (Table 5), and differed significantly $(\mathrm{p}<0.01)$ from the non-irrigated group, which presented great amounts of peaberry beans (21.8\%). As previously stated, the production of peaberries is partly related to adverse environmental factors, mainly in the flowering and fruiting. Appropriate management of irrigation in these phases provided better conditions for the formation of beans, thus reducing the percentage of peaberries.

The curves of bean distribution according to the grades of sieves in the irrigated treatments showed a displacement to the right side in the grading of sieves when compared with the curves obtained by the non-irrigated ones (Figure 2). The distribution of beans in the irrigated crops was from sieve 14 up to 23 , regardless of population arrangement. In the non-irrigated crops, the distribution occurred from sieve 13 up to 22.

All curves of bean distribution in the different grades of sieves have a negative asymmetric distribution (Table 6). The non-irrigated treatments presented a greater coefficient of asymmetry, i.e., larger distance from symmetry and greater tail to the left side. Distribution curves of bean with 
a high degree of asymmetry are undesirable in coffee crops. The heterogeneity of bean size affects the roasting process due to the lack of roasting uniformity of the beans, impairing the quality of the drink.
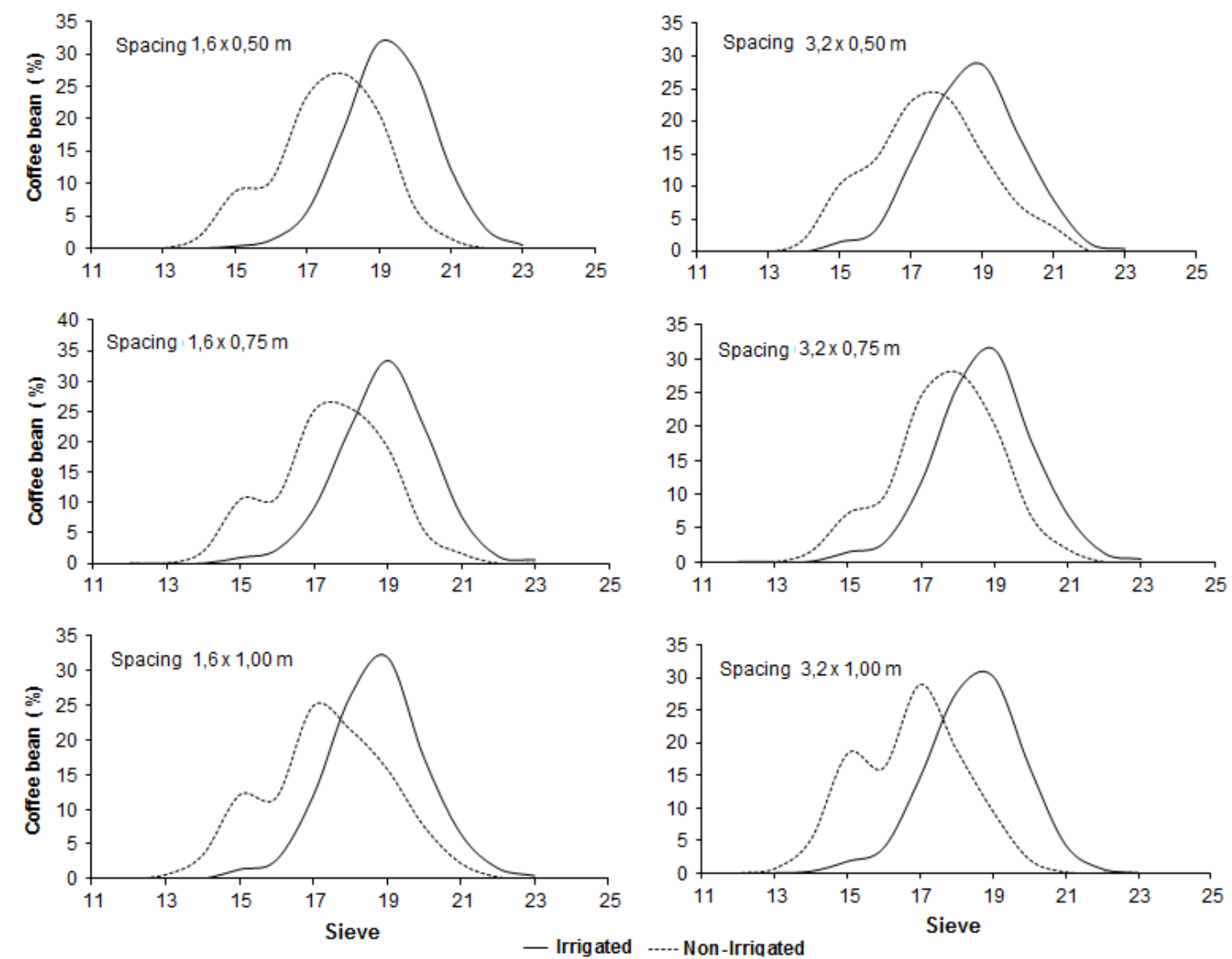

FIGURE 2. Distribution of coffee beans, in percentage, in different grades of sieves and population arrangements, with or without irrigation, in Mococa - SP, Brazil.

TABLE 6. Standard deviation $(\sigma)$ according to Pearson and coefficient of asymmetry $\left(\mathrm{e}_{2}\right)$, of the frequency distribution of beans in different grades of sieves and population arrangements, with or without irrigation, in Mococa - SP, Brazil.

\begin{tabular}{cccc}
\hline Irrigation & Population Arrangements & $\sigma$ & $\mathrm{e}_{2}$ \\
\hline \multirow{3}{*}{ With } & $1.60 \times 0.50$ & 9.981 & -0.299 \\
& $1.60 \times 0.75$ & 10.855 & -0.153 \\
& $1.60 \times 1.00$ & 10.043 & -0.153 \\
& $3.20 \times 0.50$ & 8.196 & -0.189 \\
& $3.20 \times 0.75$ & 9.709 & -0.161 \\
& $3.20 \times 1.00$ & 9.434 & -0.177 \\
\hline \multirow{6}{*}{ Without } & $1.60 \times 0.50$ & 7.735 & -0.235 \\
& $1.60 \times 0.75$ & 7.508 & -0.230 \\
& $1.60 \times 1.00$ & 7.263 & -0.214 \\
& $3.20 \times 0.50$ & 7.032 & -0.212 \\
& $3.20 \times 0.75$ & 8.350 & -0.206 \\
& $3.20 \times 1.00$ & 7.613 & -0.235 \\
\hline
\end{tabular}

\section{CONCLUSIONS}

In the first years of Catuaí coffee crop cultivation, the adoption of irrigation is more advantageous in denser crops, ensuring higher production of processed coffee. 
Plants in the irrigated group presented better phytometric development than those in the nonirrigated one. Additionally, interaction between population arrangement and irrigation could be seen, with an increase in plant height and diameter as the spacing was reduced.

The adoption of irrigation technique provided an increase in the size of beans. The nonirrigated group presented greater percentage of peaberry bean when compared to the irrigated one, which highlight the potential of irrigation both to add value and to ensure export quality standards.

\section{REFERENCES}

ALLEN, R.G.; PEREIRA, L.S.; RAES, D.; SMITH, M. Crop evapotranspiration - guidelines for computing crop water requirements. In: FAO. Irrigation and Drainage. Roma, 1998. 300 p.

CAMARGO, A.P.; CAMARGO, M.B.P. Definição e esquematização das fases fenológicas do cafeeiro arábica nas condições tropicais do Brasil. Bragantia, Campinas, v.60, n.1, p.65-68, 2001.

CARVALHO, C.H.M.; COLOMBO, A.; SCALCO, M.S.; MORAIS; A.R. de. Evolução do crescimento do cafeeiro (Coffea arabica L.) irrigado e não irrigado em duas densidades de plantio. Ciência Agrotecnologia, Lavras, v.30, n.2, p.243-250, 2006.

COSTA, A.R.; REZENDE, R.; FREITAS, P.S.L.; FRIZZONE, J.A.; HELBEL Jr. Número de ramos plagiotrópicos e produtividade de duas cultivares de cafeeiro utilizando irrigação por gotejamento. Revista Ciência Agronômica, Fortaleza, v.41, n.4, p.571-581, 2010.

CUSTÓDIO, A.A.P.; GOMES, N.M.; LIMA, L.A. Efeito da irrigação sobre a classificação do café. Engenharia Agrícola, Jaboticabal, v.27, n.3, p.691-701, 2007.

EMBRAPA. Sistema Brasileiro de Classificação de Solos. Brasília, 2006. 306 p.

FAO. FAOSTAT Data base Query. Disponível em: <http://faostat.fao.org/>. Acesso em: 07 fev. 2008.

FAZUOLLI, L.C.; GALLO, P.B.; CERVELLINI, G.J.; BARROS, I.; RAIJ, B. Van. Café. In: FAHL, J. I.; CAMARGO, M. B. P.; PIZZINATO, M. A. P.; BETTO, J. A.; MELOS, A. M.; MARIA, J. C. de; FURLANI, A. M. C. (Ed.). Instruções Agrícolas para as principais culturas. Campinas: Instituto Agronômico, 1998. 396 p. (Boletim 200)

FLUMIGNAN, D.L.; FARIA, R.T.; PRETE, C.E.C. Evapotranspiration components and dual crop coefficients of coffee trees during crop production. Agricultural Water Management, Amesterdam, v. 98, n.5, p.791-800, 2011.

FREITAS, Z.M.T.S.; OLIVEIRA, F.J.; CARVALHO, S.P.; SANTOS, V.F.; SANTOS, J.P.O. Avaliação de caracteres quantitativos relacionados com o crescimento vegetativo entre cultivares de café arábica de porte baixo. Bragantia, Campinas, v.66, n.2, p.267-275, 2007.

MARTINEZ, H.E.P.; AUGUSTO, H.S.; CRUZ, C.D.; PEDROSA, A.W.; SAMPAIO, N.F. Crescimento vegetativo de cultivares de café (Coffea arábica L.) e sua correlação com a produção em espaçamento adensado. Acta Scientinarium Agronomy, Maringá, v.29, n.4, p.481-489, 2007.

MOREIRA, R.C.; FURLANI JUNIOR, E.; HERNANDEZ, F.B.T.; FURLANI, R.C.M. Espaçamentos para cafeeiro (Coffea arabica L.) com e sem emprego da irrigação. Acta Scientiarium Agronomy, Maringá, v.26, n.1, p.73-78, 2004.

NACIF, A. P. Fenologia e produtividade do cafeeiro (Coffea arabica L.), cv Catuaí sob diferentes densidades de plantio e doses de fertilizantes, no cerrado de Patrocínio - MG. 1997. 124 f. Tese (Doutorado) - Universidade Federal de Viçosa, Viçosa, 1997.

PAIVA, L.C. Periodicidade de crescimento do cafeeiro (Coffea arábica L.) em diferentes tensões de irrigação e duas densidades de plantio. 2006. 90 f. Tese (Doutorado) - Universidade Federal de Lavras, Lavras, 2006. 
PEREIRA, S.P.; GUIMARÃES, J.R.; BARTHOLO, G.F.; GUIMARÃES, P.T.G.; ALVES, J.D. Crescimento vegetativo e produção de cafeeiros (Coffea arabica L.) recepados em duas épocas, conduzidos em espaçamentos crescentes. Ciência e Agrotecnologia, Lavras, v.31, n.3, p.643-649, 2007.

PEZZOPANE, J.R.M.; PEDRO JÚNIOR, M.J.; GALLO, P.B.; CAMARGO, M.B.P.; FAZUOLI, L.C. Avaliações fenológicas e agronômicas em café arábica cultivado a pleno sol e consorciado com banana prata anã. Bragantia, Campinas, v.66, n.4, p.527-533, 2007.

QUAGGIO, J.A.; RAIJ, B.Van. Fertirrigação: novo ambiente de produção da cafeicultura. In: CURSO DE ATUALIZAÇÃO EM CAFÉ, 9., 2009, Campinas. p.25-39. (Documento IAC, 91).

REZENDE, F.C.; OLIVEIRA, S.R.; FARIA, M.A.; ARANTES, K.R. Característica produtiva do cafeeiro (Coffea arabica L. cv., Topázio MG - 1190), recepado e irrigado por gotejamento. Coffea Science, Lavras, v.1, n.2, p.103-110, 2006.

ROLIM, G.S.; CAMARGO, M.B.P.; LANIA, D.G.; MORAES, J.F.L. Classificação climática de Köeppen e de Thornthwaite e sua aplicabilidade na determinação de zonas agroclimáticas para o estado de São Paulo. Bragantia, Campinas, v.66, n.4, p.711-720, 2007.

SANTOS, M.L. Espaçamentos para cafeeiro (Coffea arabica L.) com e sem irrigação em região de cerrado. 2005. 44f. Dissertação (Mestrado). Universidade Estadual Paulista, Faculdade de Engenharia de Ilha Solteira, Ilha Solteira, 2005.

SILVA, C.A.; TEODORO, R.E.F.; MELO, B. Produtividade e rendimento do cafeeiro submetido a lâminas de irrigação. Pesquisa Agropecuária Brasileira, Brasília, v.43, n.3, p.387-394, 2008.

SILVA, E.A.; BRUNINI, O.; SAKAI, E.; ARRUDA, F.B.; PIRES, R.C.M. Influência de déficit hídrico controlado na uniformização do florescimento e produção do cafeeiro em três diferentes condições edafoclimáticas do Estado de São Paulo. Bragantia, Campinas, v.68, n.2, p.493-501, 2009.

TAIZ, L.; ZEIGER, E. Fisiologia vegetal. Porto Alegre: Artmed, 2008. 820 p. 